\title{
Indicators to evaluate water sensitive urban design in urban planning
}

\author{
M. I. Rodríguez ${ }^{1}$, M. M. Cuevas ${ }^{1}$, F. Huertas ${ }^{1}$, G. Martínez $^{2}$ \\ \& B. Moreno ${ }^{2}$ \\ ${ }^{I}$ Department of Urban and Regional Planning, \\ University of Granada, Spain \\ ${ }^{2}$ Department of Construction and Engineering Projects, \\ University of Granada, Spain
}

\begin{abstract}
Concern about integrated water management in cities has been present in different forms in urban planning since the beginning of the explosion of cities in the late 18th century. The rapid growth of industrial cities in the late 18th century meant development was necessary to improve transit. This urbanization meant that the underground channelling of rainwater and sewage and the impermeabilization of the streets in order for them to cope with increasing circulation. These two principles were present in the development of urban services during the 19th and 20th centuries but they have also been questioned by the latest planning trends such as "Urban Ecology" or "Ecological Urbanism". They demand more sustainable urban design in which the natural water flow is recovered. "Sustainable Urban Drainage Systems" were created in the nineties as a new model of sustainable storm- water management. They have made it possible to integrate water in urban processes, advancing to "Water Sensitive Urban Design." This new working method has not been developed yet, so it is necessary to establish methodologies that help planners to plan water sensitive cities. The definition of indicators that assess the integration of water in urban design is the main goal of this research. It will be necessary to define a set of indicators to reflect essential concepts that have to be incorporated into Water Sensitive Urban Design.

Keywords: indicator, urban planning, water sensitive urban design, sustainable urban drainage systems, SUDS.
\end{abstract}




\section{Introduction}

Preoccupation about the integration of water in cities has been present in urban planning, in one form or another, since the phenomenon of the explosion of cities at the end of the $18^{\text {th }}$ century. The rapid growth of industrial cities led to the creation of insanitary neighbourhoods with no urban services, into which immigrant populations were crammed. They finally became affected by the serious health problems caused by from the accumulation of residual water on the streets [1]. This obliged the experts of the period to develop urbanization projects (paving, sanitation and provisions) which consisted of the underwater channeling of rainwater and sewage and in the impermeabilization of urban surfaces, in order to make transit more comfortable [2]. The main projects of the period (Plan Haussmann in Paris, 1953; Plan Cerdá in Barcelona, 1860) were the result of the need for the "modernization" of cities, the main objective of which was to sanitize cities and make them accessible [3].

This aim to eliminate street water and make their surfaces impermeable, established a management model which separated water treatment form urban space design, and which became cemented in our cities throughout the $19^{\text {th }}$ and $20^{\text {th }}$ centuries. In spite of this, ever since the beginning of the $19^{\text {th }}$ century plans, such as those of Olmsted in 1867, provided, with their projects, (Central Park and Prospect Park in New York, Riverside and South Park in Chicago, Esmerald Necklace in Boston) a new vision of the relationship between planning, open space and water, proposing the creation of new "green corridors" and organized networks of parks which allowed cities to be cleaned up, while also improving the well-being of citizens through a more integrated approach [4]. In line with this, Patrick Geddes in his 1910 work "Valley Section", spoke of the need to plan taking into consideration the relationship with water, understanding the geographical and hydrological unit, going beyond the purely urban context [5]. In 1960 in his publication "Design with nature" [6], McHarg indicated that a biunique relationship between planning and water management existed and introduced the need to perform studies which, through the superimposing of layers of information, detected the most appropriate zones for developing projects, searching for "Sustainability" in urban planning. In the 80s, the concept of "Ecological Urbanism" [7] was introduced, which considered cities to be capable of adapting to conditions and changing needs (resilient cities [8]), where water became an important variable to be considered.

To sum up, all these urban currents demanded more sustainable urban design, in which the natural flow of water in relation to cities could be recovered. However, the reality of urban planning has been very different. The expansion process of built-up areas has generated an uncontrolled increase in impermeable surface area [9], which is having serious consequences for cities and their residents [10-12]. A loss of biodiversity and natural habitats, [13, 14], and agricultural and forestry land [15-17], has occurred and it has increased the temperature in urban environments (the "Heat Island" effect), generating problems for human health. It has also increased energy consumption $[18,19]$. 
Likewise, the impermeabilization of surface areas is having serious consequences for the urban water cycle, altering the natural filtering capacity of soil and causing the numerous contaminants generated by human activity to finish up degrading the bodies of water [20]. Similarly, the reduction in the infiltration and retention capacity of the soil has increased the amount of surface run-off generated and its speed. This has created a situation of insufficiency of the traditional sanitation networks, which do not have the capacity to empty the growing volumes generated by new urban developments [9]. This means that the original network units, the majority of which were widened at the end of the 19th century, and expanded to their limits throughout the 20th century, have proved to be insufficient, generating an unsustainable and inefficient management model. This situation requires new ways of treating urban drainage, going beyond the traditional idea of "sanitizing the city" [9].

To this end, since the beginning of the $90 \mathrm{~s}$, a new strategy is being suggested which is more in accordance with environmental principles and quality of life. This has as its main objective the alleviation of the effects generated by the impermeabilization of cities [11], through the application of the named "Sustainable Urban Drainage Systems" or SUDS [21, 22]. Also known as BMP (Best Management Practice) or LID (Low Impact Development), these systems collect rain water, transport it and store it for the maximum time possible with the aim of slowing it down and later it is filtered and reused for non-consumptive use or simply for the refilling of aquifers [21]. A wide range of technical manuals currently exist which help us to design and implant these systems [2123], however they can be complicated to apply due to their high technical content. In addition, on many occasions their implementation is being performed solely to mitigate the effects of incorrect planning. In spite of this the implementation of SUDS has proved to be a very useful tool for integrating water in urban processes, advancing towards what has been recently named as "Water Sensitive Urban Design" (WSUD); the integration of urban planning into the management, protection and conservation of the urban water cycle, in such a way that water management which is sensitive to hydrological and ecological processes is guaranteed [24].

Currently, there are still very few references which work to this idea [25], which makes developing specific methodologies directed at urban planners (going further than the technical manuals which already exist) necessary. Methodologies which focus more strongly on the design of solutions and their integration in urban and landscape planning [9]. To achieve this, indicators are a useful tool, as with them it is possible to evaluate water integration in urban planning, therefore allowing the urban planners to develop and validate their proposals. This is the main aim of this paper; to define a set of indicators which reflect those basic aspects which need to be incorporated into planning so that it responds to the requirements of Water Sensitive Urban Design. 


\section{Objectives}

The main objective of this paper is to establish a set of indicators which determine the basic aspects which should be considered in the integration of water in urban planning, helping planners to define and validate their projects in accordance with the principles of Water Sensitive Urban Design.

\section{Methodology}

The use of indicators in urban planning is a widespread practice, as it improves the planning process by considering the possibility of measurement and develops criteria, indicators and standards which allow improvement in effectiveness, taking advantage of opportunities, driving strengths and correcting defects [26]. On the other hand, they give support to decision making for the agents involved in planning, providing information about existing problems, establishing priorities, improving the monitoring of the planning process, diffusion and the involvement of the public [27], establishing evaluation methods of the problems detected in the territory [28].

In this regard, the creation of indicators which allow the evaluation of water integration in planning will help to define and quantify said integration, generating an important advance in the definition and application of WSUD.

In order to develop these indicators, the method which is summarized in figure 1 has been used. The first step consists of defining the targets since the necessary criteria to select indicators are based mainly on the fulfillment of the objectives for which they have been defined [29]. In this case, the main targets which WSUD sets can be summarized in two parts: ensure sensitive water management for hydrological and ecological processes, recovering the natural flow of water cycles in cities, and integrate urban planning in the management, protection and conservation of the urban water cycle [24].

To reach these targets, it will be necessary to develop measures which infiltrate, retain, treat and reuse rainwater, to some extent "reproducing" the natural characteristics of the soils before they were urbanized. Furthermore, guidelines should be established which integrate both disciplines, therefore assuring that the proposals which have been defined by planning are in accordance with hydrological processes and vice versa. It is also necessary to establish coordination mechanisms which ensure the interdisciplinary nature of technical teams and, accordingly, the consideration of all aspects concerning water and its relationship with the other urban services. Finally, social agents must be involved in the planning process in order to guarantee the success of the proposals which are carried out as well as for maintaining the adopted measures.

All of these measures will generate a series of benefits which could be quantified through the application of indicators, allowing the proposals which have been carried out to be evaluated and establishing the degree to which the initial objectives have been fulfilled [30]. The main benefits generated for the proposed measures for WSUD are summarized in table 1. Once the benefits of WSUD are established, these should be quantified through the definition of 
the associated indicators. To achieve this, firstly, a revision of the bibliography of general environmental indicators defined by other authors has been done, in order to locate those which could be implemented in WSUD. In table 2 a summary of the main sources which were consulted is shown.

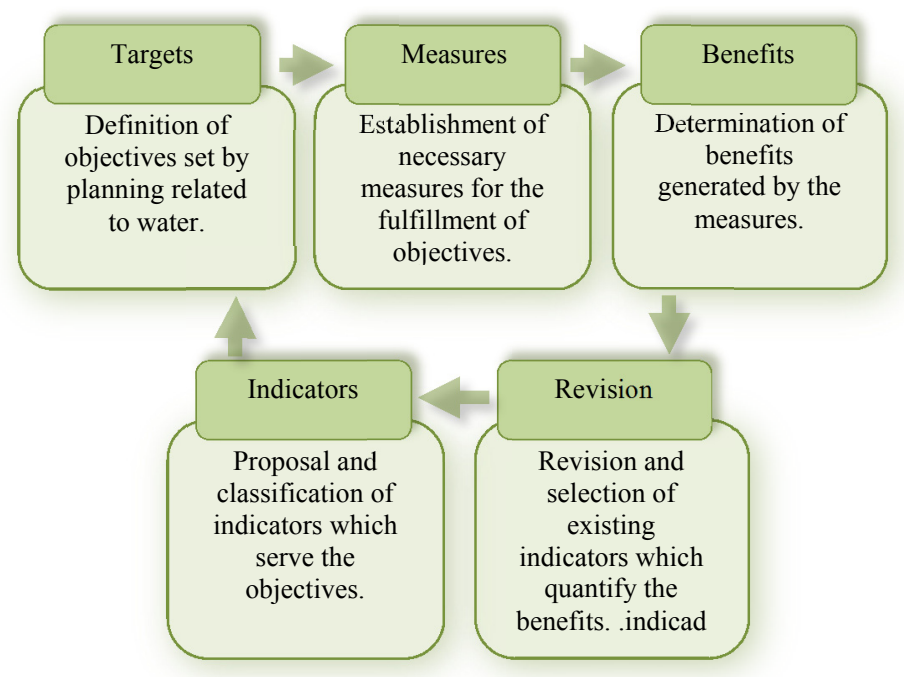

Figure 1: $\quad$ Proposed methodology for the definition of WSUD indicators.

Table 1: $\quad$ Targets, measures and benefits of WSUD.

\begin{tabular}{|c|c|c|}
\hline TARGETS & MEASURES & BENEFITS \\
\hline \multirow{11}{*}{$\begin{array}{l}\text { Recover the } \\
\text { natural flow of } \\
\text { the water cycle } \\
\text { in cities }\end{array}$} & \multirow{3}{*}{ Infiltrate } & Increase available groundwater resources \\
\hline & & Increase available surface water resources \\
\hline & & Decrease the "Heat Island Effect" \\
\hline & \multirow{3}{*}{ Retain } & Decrease rainwater contamination \\
\hline & & Decrease the risk of flooding \\
\hline & & Improve the service conditions of cities \\
\hline & \multirow[t]{2}{*}{ Treat } & $\begin{array}{l}\text { Improve the hydrological functions of river } \\
\text { basins }\end{array}$ \\
\hline & & Create green infrastructure \\
\hline & \multirow{3}{*}{ Reuse } & Improve the efficiency of water networks \\
\hline & & Recover degraded areas \\
\hline & & Improve air quality \\
\hline \multirow{3}{*}{$\begin{array}{l}\text { Integrate urban } \\
\text { planning in } \\
\text { water } \\
\text { management. }\end{array}$} & \multirow{3}{*}{$\begin{array}{l}\text { Legislation } \\
\text { Coordination } \\
\text { Stakeholder } \\
\text { engagement }\end{array}$} & Implementation of WSUD in planning through \\
\hline & & Multidisciplinarity and integration of urban \\
\hline & & $\begin{array}{l}\text { Proper functioning of proposals, involving social } \\
\text { agents in the projects and monitoring }\end{array}$ \\
\hline
\end{tabular}


Table 2: References, environmental indicators.

ORGANIZATION/AUTHOR, YEAR
Agencia d'ecologia Urbana de Barcelona,
2014. [31]
Centre for Urban Policy Studies, 2008.
[32]
Chow, J., Savic, D., Fortune, D., Kapelan,
Z., and Mebrate, N., 2014. [33]
European Environment Agency, EEA,
2006. [34]

European Commission, EC, 2000. [35]

Economic Commission for Latin America and the Caribbean, ECLAC, 2009. [36]

Hourneaux Jr, F., Atila, H., and Maffini, C., 2014. [37]

Khalil, B., Ouarda, T., St-Hilaire, A., and Chebana, F., 2010. [38]

Mazzi, A., Mason, C., Mason, M., and Scipioni, A., 2012. [39]

Moldan, B., Janousková, S., and Hák, T., 2012. [40]

Nordin, M., and Hezri, A., 2004. [41]

Organisation for Economic Co-operation and Development, OECD., 1998. [42] Peris-Mora, E., Días-Orejas, J., Subirats, A., Ibáñez, S., and Álvarez, P., 2005. [43]

Puig, M., Wooldridge, C., and Darbra, R., 2014. [44]

Soria, J., and Valenzuela, L., 2013. [28]

University of Yale. Centre for

Environmental Law and Policy, 2005. [45]

Valenzuela, L., and Matarán, A., 2008. [46]

Zuraco, A., Ripa, M., Mellino, S., Ascione, M., and Ulgiati, S.. 2014. [47]

\section{TITLE}

Certificación del Urbanismo Ecológico

Measuring the Outcomes of Spatial Planning in England

Using a systematic, multi-criteria decision support framework to evaluate sustainable drainage designs

EEA core set of indicators - Guide

The New Programming period 2000-2006: methodological working papers. Indicators for Monitoring and Evaluation

Guía metodológica Diseño de indicadores compuestos de desarrollo sostenible The use of environmental performance indicators and size effect: A study of industrial companies

A statistical approach for the rationalization of water quality indicators in surface water quality monitoring networks

Is it possible to compare environmental performance indicators reported by public administrations? Results from an Italian survey

How to understand and measure

environmental sustainability: Indicators and targets

Management framework for sustainable development indicators in the State of Selangor, Malaysia

Core Set of Indicators of Development Progress

Development of a system of indicators for sustainable port management

Identification and selection of Environmental

Performance Indicators for sustainable port development.

A Method for the Evaluation of Metropolitan Planning: Application to the Context in Spain

2005 Environmental Sustainability Index.

Environmental indicators to evaluate spatial and water planning in the coast of Granada (Spain)

Urban resources and environmental performance indicators.

After analyzing the main environmental indicators which already exist, the subsequent process has been followed. The indicators have been classified into 
three types; those which are suitable for application in WSUD, those which are related but require modification and those which are not directly related. The first ones have been selected, the second ones have been adapted and the third ones have been discarded. To each of the selected and adapted indicators the quantified benefit has been given and for those benefits which have not been matched to an indicator a new one has been assigned starting from zero. Once this process has been carried out, it is checked that all of the benefits can be quantified using indicators, and that they meet all the previously defined indicators. If this is not the case, the process should be repeated, reviewing the proposed measurements, the generated benefits and the defined indicators, until it is assured that all targets have been reached (Figure 1).

\section{Results: indicators for water sensitive urban design}

Following the methodology prosed in the previous section, a series of indicators have been obtained which allow the degree of suitability of urban proposals to be quantified, based on the principles of WSUD. These indicators have been classified into 7 categories according to the main subject which they quantify (Table 3). Therefore, in order to evaluate a proposal, calculating each indicator to obtain a global value for each subject is enough.

To compare proposals with each other, a STAR diagram can be produced in which each vertex corresponds to one of the defined subjects. Therefore, the area defined by the values obtained will represent the suitability of the proposal; the larger the area, the more suitable it is. For example, in the case of the flooding problem of an urban area two types of proposal could be carried out, one of which would be more structural, based on the construction of a storm drain system which retains rainwater and the other, less structural, based on repaving with permeable surfaces and installing green roofs which infiltrate and retain rainwater.

If we apply the defined indicators to these two theoretical proposals, we will obtain values which after being represented on a graph, will give us an area value of 33.78 for the first proposal and 51.14 for the second, making the second more suitable (Figure 2). This result is reasonable as the principles of WSUD follow the use of measures which are more in line with urban design.
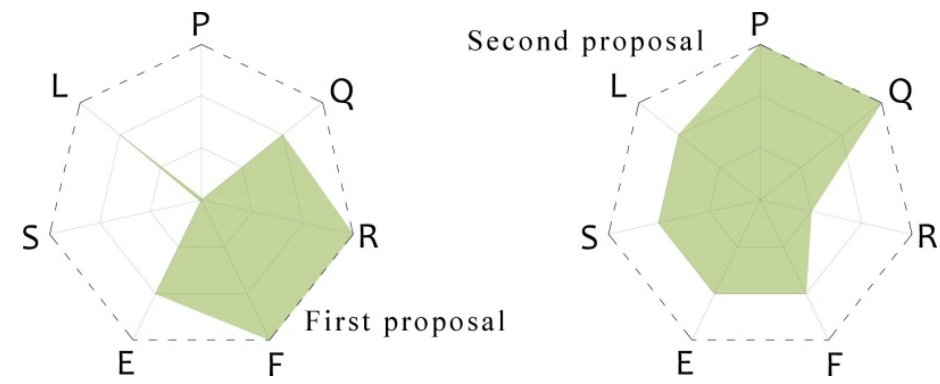

Figure 2: Example of the application of WSUD indicators. 
Table 3: Indicators for water sensitive urban design.

\begin{tabular}{|c|c|c|c|}
\hline SUBJECTS & INDICATORS & DESCRIPTION & UNIT \\
\hline \multirow{6}{*}{ Permeability } & $\begin{array}{l}\text { Permeable road } \\
\text { surfaces }\end{array}$ & $\begin{array}{l}\text { Surface area of permeable road in relation to } \\
\text { total pavement surface area }\end{array}$ & $\%$ \\
\hline & $\begin{array}{l}\text { Permeable } \\
\text { pavements }\end{array}$ & $\begin{array}{l}\text { Surface area of permeable pavement in relation } \\
\text { to total pavement surface area }\end{array}$ & $\%$ \\
\hline & $\begin{array}{l}\text { Permeable car } \\
\text { parks }\end{array}$ & $\begin{array}{l}\text { Surface area of permeable car parks in relation } \\
\text { to total car park surface area }\end{array}$ & $\%$ \\
\hline & $\begin{array}{l}\text { Permeable public } \\
\text { spaces }\end{array}$ & $\begin{array}{l}\text { Surface area of permeable public spaces in } \\
\text { relation to total public space surface area }\end{array}$ & $\%$ \\
\hline & Green surfaces & $\begin{array}{l}\text { Green surface area in relation to total surface } \\
\text { area }\end{array}$ & $\%$ \\
\hline & Green roofing & $\begin{array}{l}\text { Surface area of green roofing in relation to } \\
\text { total roof surface area }\end{array}$ & $\%$ \\
\hline \multirow{5}{*}{$\begin{array}{l}\text { Environmental } \\
\text { quality }\end{array}$} & Air quality & Presence of contaminants in the atmosphere & $\mathrm{g} / \mathrm{m}^{3}$ \\
\hline & Regenerated areas & $\begin{array}{l}\text { Surface area of regenerated areas in relation to } \\
\text { total surface area }\end{array}$ & $\%$ \\
\hline & $\begin{array}{l}\text { Rainwater } \\
\text { contamination }\end{array}$ & $\begin{array}{l}\text { Level of rainwater contamination arriving at } \\
\text { WWTP }\end{array}$ & $\begin{array}{l}\text { BOD, } \\
\text { COD }\end{array}$ \\
\hline & $\begin{array}{l}\text { Groundwater } \\
\text { contamination }\end{array}$ & Level of soil contamination & $\begin{array}{l}\text { BOD, } \\
\text { COD }\end{array}$ \\
\hline & Temperature & Temperature of the surface area of the soil & ${ }^{\circ} \mathrm{C}$ \\
\hline \multirow{3}{*}{$\begin{array}{l}\text { Water } \\
\text { resources }\end{array}$} & Infiltrated water & $\begin{array}{l}\text { Volume of infiltrated water in regard to } \\
\text { precipitation }\end{array}$ & $\%$ \\
\hline & Retained water & $\begin{array}{l}\text { Volume of retained water in regard to } \\
\text { precipitation }\end{array}$ & $\%$ \\
\hline & Reused water & $\begin{array}{l}\text { Volume of reused water in regard to } \\
\text { precipitation }\end{array}$ & $\%$ \\
\hline \multirow{6}{*}{ Flooding } & Flooding events & $\begin{array}{l}\text { Number of flooding episodes in the } \\
\text { hydrological year }\end{array}$ & No. \\
\hline & Flood-prone areas & $\begin{array}{l}\text { Surface area of flood-prone area in regard to } \\
\text { total surface area }\end{array}$ & $\%$ \\
\hline & Traffic incidents & $\begin{array}{l}\text { Number of traffic incidents caused by the } \\
\text { accumulation of rainwater on the streets }\end{array}$ & No. \\
\hline & Other incidents & $\begin{array}{l}\text { Number of other incidents caused by the } \\
\text { accumulation of rainwater on the streets }\end{array}$ & No. \\
\hline & $\begin{array}{l}\text { Concentration } \\
\text { time. } T_{c}\end{array}$ & $\begin{array}{l}\text { Time required for the water from the furthest } \\
\text { point to arrive at the exit of the water basin }\end{array}$ & Min \\
\hline & $\begin{array}{l}\text { Maximum flow. } \\
Q_{p}\end{array}$ & $\begin{array}{l}\text { Maximum run-off flow generated by one } \\
\text { rainfall }\end{array}$ & $\mathrm{m}^{3} / \mathrm{h}$ \\
\hline
\end{tabular}


Table 3: Continued.

\begin{tabular}{|c|c|c|c|}
\hline SUBJECTS & INDICATORS & DESCRIPTION & UNIT \\
\hline \multirow{2}{*}{$\begin{array}{l}\text { Efficiency } \\
\text { network }\end{array}$} & $\begin{array}{l}\text { Management } \\
\text { errors }\end{array}$ & $\begin{array}{l}\text { Number of incidents in the management of } \\
\text { water networks due to rain events }\end{array}$ & No. \\
\hline & $\begin{array}{l}\text { Management } \\
\text { costs }\end{array}$ & Management costs of sanitary network & $€$ \\
\hline \multirow{3}{*}{$\begin{array}{l}\text { Stakeholder } \\
\text { engagement }\end{array}$} & $\begin{array}{l}\text { Public } \\
\text { participation }\end{array}$ & $\begin{array}{l}\text { Number of events which promote community } \\
\text { participation }\end{array}$ & No. \\
\hline & $\begin{array}{l}\text { Proposals } \\
\text { presented by } \\
\text { communities }\end{array}$ & $\begin{array}{l}\text { Number of public proposals presented to the } \\
\text { technical team }\end{array}$ & No. \\
\hline & $\begin{array}{l}\text { Proposals } \\
\text { collected in } \\
\text { planning }\end{array}$ & $\begin{array}{l}\text { Number of public proposals collected in } \\
\text { planning }\end{array}$ & No. \\
\hline \multirow{4}{*}{$\begin{array}{l}\text { Legislation } \\
\text { and water } \\
\text { governance }\end{array}$} & Interdisciplinarity & $\begin{array}{l}\text { Number of disciplines participating in the } \\
\text { technical team }\end{array}$ & No. \\
\hline & $\begin{array}{l}\text { Guideline } \\
\text { integration }\end{array}$ & $\begin{array}{l}\text { Number of guidelines which integrate water } \\
\text { planning and management }\end{array}$ & No. \\
\hline & $\begin{array}{l}\text { Administrative } \\
\text { integration }\end{array}$ & $\begin{array}{l}\text { Number of technical documents which } \\
\text { integrate water planning and management }\end{array}$ & No. \\
\hline & $\begin{array}{l}\text { WSUD } \\
\text { observatory }\end{array}$ & $\begin{array}{l}\text { Existence of an observatory which values and } \\
\text { evaluated WSUD }\end{array}$ & $\begin{array}{l}\text { Yes- } \\
\text { No }\end{array}$ \\
\hline
\end{tabular}

In summary, it can be stated that the methodology which has been created allows the evaluation of urban proposals regarding their relationship with WSUD, helping decision making on the part of social agents, experts and politicians.

\section{Conclusions}

As shown, it is necessary to define methodologies which allow definition of greater accuracy in Water Sensitive Urban Design and help the planners in the application of plans. In order to achieve this, this paper put forward a set of indicators which evaluate the integration of water in urban design, allowing urban planners to define and validate their proposals, and the agents who are implicated in the planning to make decisions with regarding which solutions should be carried out. This set of indicators therefore reflects those basic aspects which need to be incorporated in planning in order for this to meet the requirements of Water Sensitive Urban Design.

\section{Acknowledgements}

The authors would like to thank the ERDF of the European Union for financial support via project "Gestión Sostenible de Aguas Pluviales en Zonas Urbanas" 
of the "Programa Operativo FEDER de Andalucía 2007-2013". We also thank to Public Works Agency and Regional Ministry of Public Works and Housing of the Regional Government of Andalusia.

\section{References}

[1] Benevolo, L., Historia de la arquitectura moderna ( $8^{\mathrm{a}}$ edición, revisada y ampliada ed.). Barcelona: Gustavo Gili.1999.

[2] López de Lucio, R., Ciudad y urbanismo a finales del siglo XX. Valencia: Universitat de Valencia, Servicio de Publicaciones.1993.

[3] Molina-Mesa, M., Del Urbanismo formal a la fantasía vanguardista. Una breve aproximación. Diálogos de Derecho y Política (Revista electrónica) 2, 1-9, 2009.

[4] Fábos, J., Greenway planning in the United States: its origins and recent case studies. Landscape and Urban Planning 68, pp. 321-342, 2004.

[5] Geddes, P., Ciudades en evolución (Vol. 18). (M. M. Vallina, Trad.) KRK Ediciones, 1960.

[6] McHarg, I. L., Design with nature. Washington: Gustavo Gili. 1967.

[7] Stearns, F., \& Montag, T., The Urban ecosystem: a holistic approach. New York: Halsted Press, 1975.

[8] Spirn, A., Ecological urbanism: a framework for the design of resilient cities. Resilience in Ecology and Urban Design. Linking theory and practice for sustainable cities. Springer Science+Business Dordrecht, 2013.

[9] Rodríguez M.I., Cuevas M.M., Martínez G. and Moreno B., Planning Criteria for Water Sensitive Urban Design. WIT Transactions on Ecology and the Environment, 191, pp. 1579-1591, 2014.

[10] Houšková, B. \& Montanarella, L., The natural susceptibility of European soils to compaction. Threats to Soil Quality in Europe. European Commission, Joint Research Centre, Institute for Environment and Sustainability, pp. 23-36, 2008.

[11] Prokop G., Jobstmann H. \& Schönbauer A., Overview on best practices for limiting soil sealing and mitigating its effects in EU-27. Environment Agency Austria, 2011.

[12] Tóth, G., Montanarella, L. \& Rusco, E., (eds).Threats to soil quality in Europe, JRC publication 46574.Office for Official Publications of the European Communities, Luxembourg, 2008.

[13] Carsjens, G., \& Van Lier, H., Fragmentation and Land-Use Planning - An introduction. Landscape and Urban Planning, 58, pp. 79-82, 2002.

[14] Gibb, H. and Hochuli, D.F., Habitat fragmentation in an urban environment: large and small fragments support different arthropod assemblages. Biological Conservation, 106, pp. 91-100, 2002.

[15] Morello, J., Buzai, G.D., Baxendale, A.B., Rodríguez, A.F., Matteucci, S.D., Godagnone, R.E. and Casas, R.R., Urbanization and the consumption of fertile land and other ecological changes: the case of Buenos Aires. Environment and Urbanization, 12(2), pp. 119-131, 2000. 
[16] Lawrence, W.T., Imhoff, M.L., Kerle, N. and Stutzer, D., Quantifying urban land use and impact on soils in Egypt using diurnal satellite imagery of the Earth surface, International Journal of Remote Sensing, 23(19), pp. 3921-3937, 2002.

[17] Chen, Z., Chen, J., Shi, P. and Tamura, M., An HIS based change detection approach for assessment of urban expansion impact on arable land loss in China. International Journal of Remote Sensing, 24(6), pp. 1353-1360, 2003.

[18] Arnfield, A. J., Two decades of urban climate research: a review of turbulence, exchanges of energy and water, and the urban heat island. International Journal of Climatology, 23(1), pp. 1-26, 2003.

[19] Gartland, L., Heat Islands: Understanding and Mitigating Heat in Urban Areas. Earthscan Publications, pp. 57-83, 2008.

[20] Ren, W., Zhong, Y., Meligrana, J., Anderson, B., Watt, W.E., Chen, J. and Leung, H.L., Urbanization, land use and water quality in Shanghai: 19471996. Environment International, 29(5), pp. 649-659, 2003.

[21] CIRIA C697, The SUDS Manual. CIRIA, London, 2007.

[22] MWB Melbourne Water Corporation, Water Sensitive Urban Design, Melbourne, 2013.

[23] SWD 101, Guidelines on best practice to limit, mitigate or compensate soil sealing. Commission Staff Working Document, 2012.

[24] COAG, Council of Australian Governments' Meeting. Celebrado en Canberra 25 Junio, 2004. Disponible en http://archive.coag.gov.au/coag meeting_outcomes/2004-06-25/index.cfm

[25] CIRIA C687, Planning for SUDS-making it happen. CIRIA, London, 2010.

[26] Gómez-Piñeiro, F., Aproximación al sistema de indicadores de calidad de la vida urbana. Lurralde. Investigación y Espacio, (32), pp. 281-299, 2009.

[27] Aguirre, M., Los sistemas de indicadores ambientales y su papel en la información e integración del medio, 2002. ambiente. I Congreso de Ingeniería Civil, Territorio y Medio Ambiente. Madrid.

[28] Soria, J., \& Valenzuela, L., A Method for the Evaluation of Metropolitan Planning: Application to the Context in Spain. European Planning Studies, 6(21), pp. 944-966, 2013.

[29] Escobar, L., Indicadores sintéticos de calidad ambiental: un modelo general para grandes zonas urbanas. Revista eure, XXXII (96), pp. 73-98, 2006

[30] Zuñiga, A., Indicadores para la evaluación de la calidad ambiental del hábitat urbano. Nexo. Revista cientifica, 22(1), pp. 23-31, 2009.

[31] Agencia d'ecologia Urbana de Barcelona, Certificación del Urbanismo Ecológico. Madrid: Ministerio de Fomento, 2014.

[32] Centre for Urban Policy Studies, Measuring the Outcomes of Spatial Planning in England. Manchester: The Royal Town Planning Institute, 2008.

[33] Chow, J., Savic, D., Fortune, D., Kapelan, Z., \& Mebrate, N., Using a systematic, multi-criteria decision support framework to evaluate 
sustainable drainage designs. Procedia Engineering, (70), pp. 343-352, 2014.

[34] EEA European Environment Agency., Urban sprawl in Europe - The ignored challenge. Copenhagen: European Environment Agency, 2006.

[35] EC, European Commission, The New Programming period 2000-2006: methodological working papers. Indicators for Monitoring and Evaluation, 2000.

[36] ECLAC, Economic Commission for Latin and Caribbean, Guía metodológica Diseño de indicadores compuestos de desarrollo sostenible. Santiago de Chile: Naciones Unidas, 2009.

[37] Hourneaux Jr, F., Atila, H., \& Maffini, C., The use of environmental performance indicators and size effect: A study of industrial companies. Ecological Indicators, (36), pp. 205-212, 2014.

[38] Khalil, B., Ouarda, T., St-Hilaire, A., \& Chebana, F., A statistical approach for the rationalization of water quality indicators in surface water quality monitoring networks. Journal of Hydrology, (386), pp. 173-185, 2010.

[39] Mazzi, A., Mason, C., Mason, M., \& Scipioni, A., Is it possible to compare environmental performance indicators reported by public administrations? Results from an Italian survey. Ecological Indicators, (23), pp. 653-659, 2012.

[40] Moldan, B., Janousková, S., \& Hák, T., How to understand and measure environmental sustainability: Indicators and targets. Ecological Indicators, (17), pp. 4-13, 2012.

[41] Nordin, M., \& Hezri, A., Management framework for sustainable development indicators in the State of Selangor, Malaysia. Ecological Indicators, (4), pp. 287-304, 2004.

[42] OCDE Organisation for Economic Co-operation and Development, Core Set of Indicators of Development Progress, 98(6), 1998.

[43] Peris-Mora, E., Días-Orejas, J., Subirats, A., Ibáñez, S., \& Álvarez, P., Development of a system of indicators for sustainable port management. Marine Pollution Bulletin, (50), pp. 1649-1660, 2005.

[44] Puig, M., Wooldridge, C., \& Darbra, R., Identification and selection of Environmental Performance Indicators for sustainable port development. Marine Pollution Bulletin, (81), pp. 124-130, 2014.

[45] University of Yale Centre for Environmental Law \& Policy, 2005 Environmental Sustainability Index. Benchmarking National Environmental Stewardship. Yale Center for Environmental Law and Policy, 2005.

[46] Valenzuela, L., \& Matarán, A., Environmental indicators to evaluate spatial and water planning in the coast of Granada (Spain). Land use Policy, (25), pp. 95-105, 2008.

[47] Zuraco, A., Ripa, M., Mellino, S., Ascione, M., \& Ulgiati, S., Urban resource use and environmental performance indicators. An application of decomposition analysis. Ecological Indicators, (47), pp. 16-25, 2014. 